Dept. of Food Hygiene,

Faculty of Veterinary Medicine, South Valley University

\title{
OCCURRENCE OF LISTERIA SPECIES IN RAW COW'S MILK \& ICE CREAM SOLD IN QENA CITY
}

(With 3 Tables and 2 Figures)

By

\section{LAILA M. EL-MALT and KARIMA G. ABDEL-HAMEED}

(Received at 17/3/2009)

تواجد ميكروبات اللستيريا في اللبن البقري الخام والأيس كريم

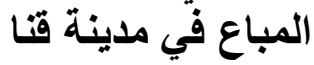

ليلى مصطفى الملط ، كريمة جلال عبل الحمبا

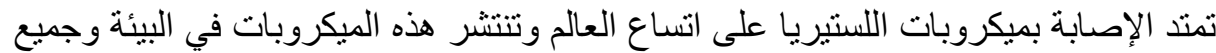

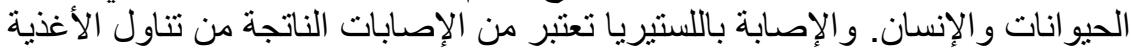

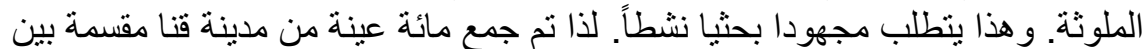

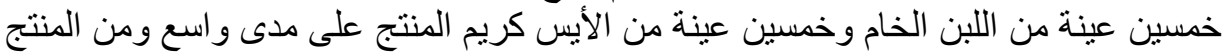

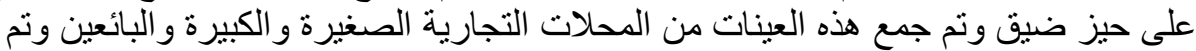

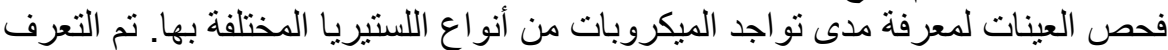

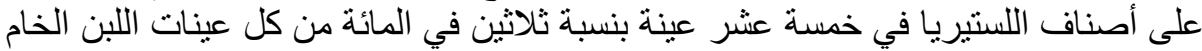

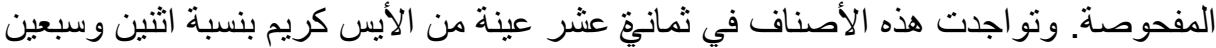

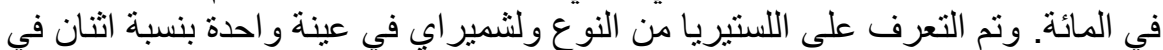

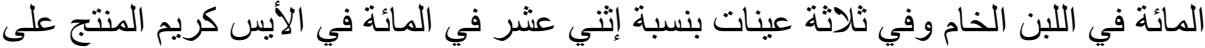

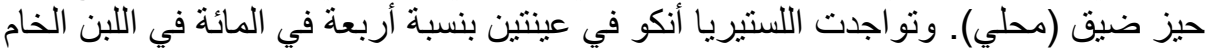

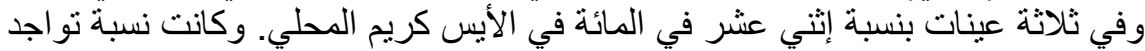

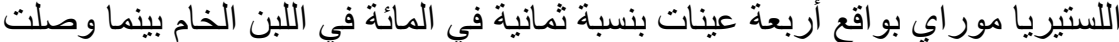

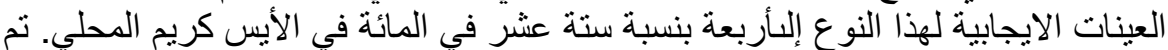

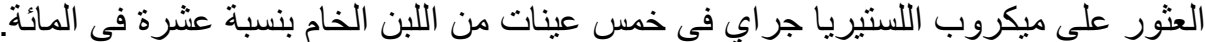

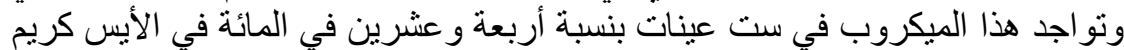

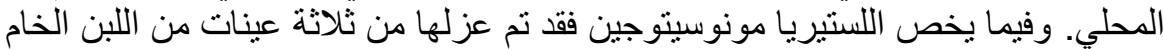

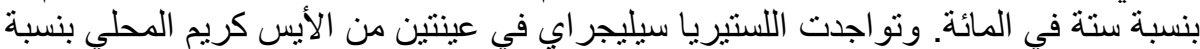

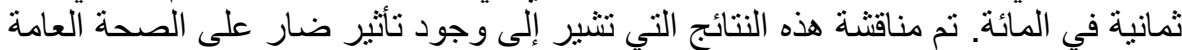

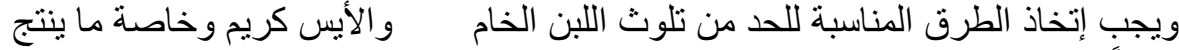
محلياً بهذه الميكروبات الهرق النامة. 


\section{SUMMARY}

Listeria infections caused by microorganisms of the genus Listeria, occur worldwide and in a variety of animals and man. Listeriosis was recognized as a food -borne human disease that prompted intense research activity. Thus a total of 100 samples including (50) raw cow's milk and (50) of both ice cream small and large scale producers purchased from retail local markets, supermarkets and street vendors in Qena city. These samples examined to investigate the occurrence of listeria species. Listeria spp. could be detected in 15(30\%) and 18(72\%) of examined raw milk and small scale ice cream samples respectively, while failed to be detected in large scale ice cream samples. L. welshimeri was identified in one sample $(2 \%)$ in raw milk, and 3 (12\%) in small scale ice cream, while $L$. inoccu present in 2 samples (4\%) of raw milk, and in 3 samples (12\%) of small scale ice cream. L. murray was isolated from 4 samples $(8 \%)$ of raw milk and 4 samples $(16 \%)$ of small scale ice cream. L. gray was detected in 5 samples $(10 \%)$ of raw cow's milk and 6 samples (24\%) of small scale ice cream. Suspected L. monocytogenes has been recovered in 3 samples $(6 \%)$ of raw milk and L. seeligeri was detected in $2(8 \%)$ of small scale ice cream. The public health importance and the recommended sanitary measures were discussed.

Key words: Listeria spp., milk, ice cream, public health.

\section{INTRODUCTION}

Listeria monocytogenes is a Gram positive, psychrotolerant food borne pathogen that is widely distributed in nature and it is the causative agent of Listeriosis, a serious invasive disease in both domestic animals and humans (Schlech et al., 1983; Farber and Peterkin, 1991; and Low and Donachie, 1997). Several outbreaks of Listeriosis associated with the consumption of milk and dairy products since 1980 and thirty percent over all mortality rate of these outbreaks were recorded (Griffiths, 1989 ).

L. monocytogenes may directly contaminate milk as a consequence of Listerial mastitis, encephalitis or Listeria-related abortion in cattle, and asymptomatic cows can also shed L. monocytogenes in their milk for many months (Hird and Genigeogis, 1990). More over under unhygienic milking practices indirect contamination of bulk milk is likely to occur if L. monocytogenes is 
present in feeds, faeces, udder surface or bedding (Fedio and Jackson, 1992).

Listeriosis in human are usually associated with the hemolytic species of Listeria (L. monocytogenes, L. ivanovii and L. seeligeri) however, $L$. welshimeri pathogenicity to human has been well documented (Cocolin et al., 2002). L. monocytogenes is the only species of the genus Listeria that has been involved in known food borne outbreaks of serious disease such as septicemia, abortion, meningioencephalitis, meningitis and gastrointestinal illness specially in immunocompromised elderly individual, pregnant women and their neonates (Longhi et al., 2003). Many surveys have been conducted and showed that L monocytogenes and other Listeria spp. could be isolated from milk and dairy products worldwide (Davison et al., 1989; ElSherbini \& Abdallah, 2003 and El-Prince \& Sayed 2004.). Likewise Listeria spp. are well equipped to survive food processing technologies. They tolerate high concentration of salt and relatively low $\mathrm{pH}$; also they are able to multiply at refrigeration temperature (Lou \& Yousef, 1999).

The reported prevalence estimates for $L$ monocytogenes in ice cream from many countries ranges from zero to $20 \%$ (Greenwood et al., 1991; Pak et al., 2002; Molla et al., 2004; Meldrun et al., 2005; ElSharef et al., 2006 and Kiss et al., 2006). Furthermore Listeria spp. have been isolated from pasteurized milk and ice cream in which contamination occurred post production or recontaminated during further handling (Jeong and Frank,1994 and El-Prince \& Sayed, 2004).

Because most of the consumed milk and dairy products are not prepared under hygienic conditions by ignorant producers, utilization of milk that is most often not boiled enough in the production of their products. This work was conducted to investigate the incidence of Listeria species in raw milk and ice cream in Qena city.

\section{MATERIALS and METHODS}

\section{Collection of samples}

A total of 100 samples including 50 raw cow's milk and 50 of both small scale and large scale ice cream samples were collected from retail local markets, supermarkets and street vendors in Qena city. Samples were investigated as soon as possible in the laboratory for the presence of Listeria spp. Milk samples were examined by Storch test to detect heat treated samples according to Lampert (1975). 


\section{Isolation of Listeria spp.:}

Detection of Literia spp. was done as described by Hitchins (1992) where one ml of milk or one gram of ice cream sanples was aseptically added to $9 \mathrm{ml}$ of Listeria enrichment broth (Biolife) and incubated at $35 \pm 1{ }^{\circ} \mathrm{C}$ for 48 hours. After incubation a loopful of enrichment broth was streaked on the surface of palcome medium and incubated at $35 \pm 1{ }^{\circ} \mathrm{C}$ for $24-48$ hours (Cutris et al., 1989).

\section{Identification of Listeria species:}

Identification was carried out according to Warburton et al., (2003) including Gram stain, catalase test, carbohydrate fermentation, Bhaemolysis on blood agar and CAMP test.

Serotyping of L monocytogenes strains:

Biochemically identified isolates were serotyped with Listeria antisera type one (Difico) by using slide agglutination test according to Difco (1984).

\section{RESULTS}

Table 1: Incidence of Listeria species in the examined samples of raw cows milk and ice cream.

\begin{tabular}{|c|c|c|c|}
\hline \multirow{2}{*}{ Types of samples } & \multirow{2}{*}{ No of tested samples } & \multicolumn{2}{|c|}{ Positive samples } \\
\cline { 3 - 4 } & & NO & $\%$ \\
\hline Raw cows milk & 50 & 15 & $30 \%$ \\
\hline Large scale ice cream & 25 & zero & zero $\%$ \\
\hline Small scale ice cream & 25 & 18 & $72 \%$ \\
\hline
\end{tabular}

Table 2: Disribution of Listeria species in positive samples of raw cow's milk and ice cream.

\begin{tabular}{|c|c|c|c|c|c|}
\hline \multirow{2}{*}{ Listeria species } & \multicolumn{2}{|c|}{$\begin{array}{c}\text { Raw cow's } \\
\text { milk }\end{array}$} & \multirow{2}{*}{$\begin{array}{c}\text { Large scale } \\
\text { ice cream }\end{array}$} & \multicolumn{2}{|c|}{$\begin{array}{c}\text { Small scale } \\
\text { ice cream }\end{array}$} \\
\cline { 2 - 3 } & No. & $\%$ & & No. & $\%$ \\
\hline L. monocytogene & 3 & $6 \%$ & zero & zero & zero \\
\hline L.seeligeri & zero & zero & zero & 2 & $8 \%$ \\
\hline L.welshimeri & 1 & $2 \%$ & zero & 3 & $12 \%$ \\
\hline L.innocua & 2 & $4 \%$ & zero & 3 & $12 \%$ \\
\hline L. murraye & 4 & $8 \%$ & zero & 4 & $16 \%$ \\
\hline L. Gray & 5 & $10 \%$ & zero & 6 & $24 \%$ \\
\hline
\end{tabular}


Table 3: Serotyping of Listeria monocytogens isolates from raw cow's milk samples.

\begin{tabular}{|l|c|c|}
\hline Types of sample & No. of suspected isolates & Serotype (1) pattern \\
\hline Raw cow's milk & 3 & 1 \\
\hline
\end{tabular}

Fig. 1: Occurrence of Listeria species in the examined raw cows milk and ice cream samples.

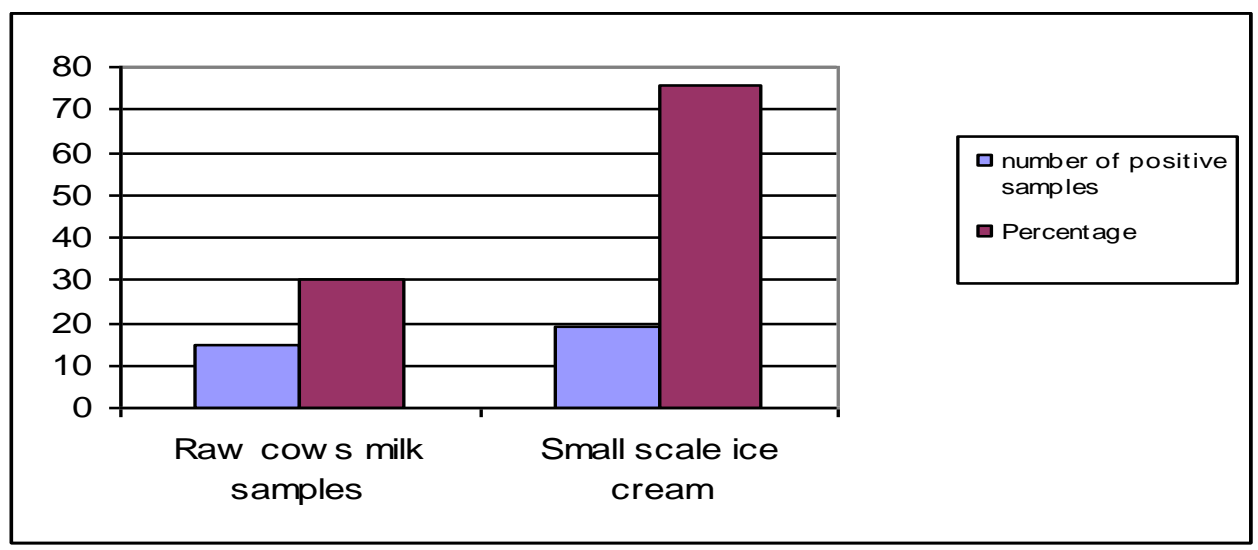

Fig. 2: Percentage of positive samples of Listeria species in the examined raw cows milk and small scale ice cream samples.

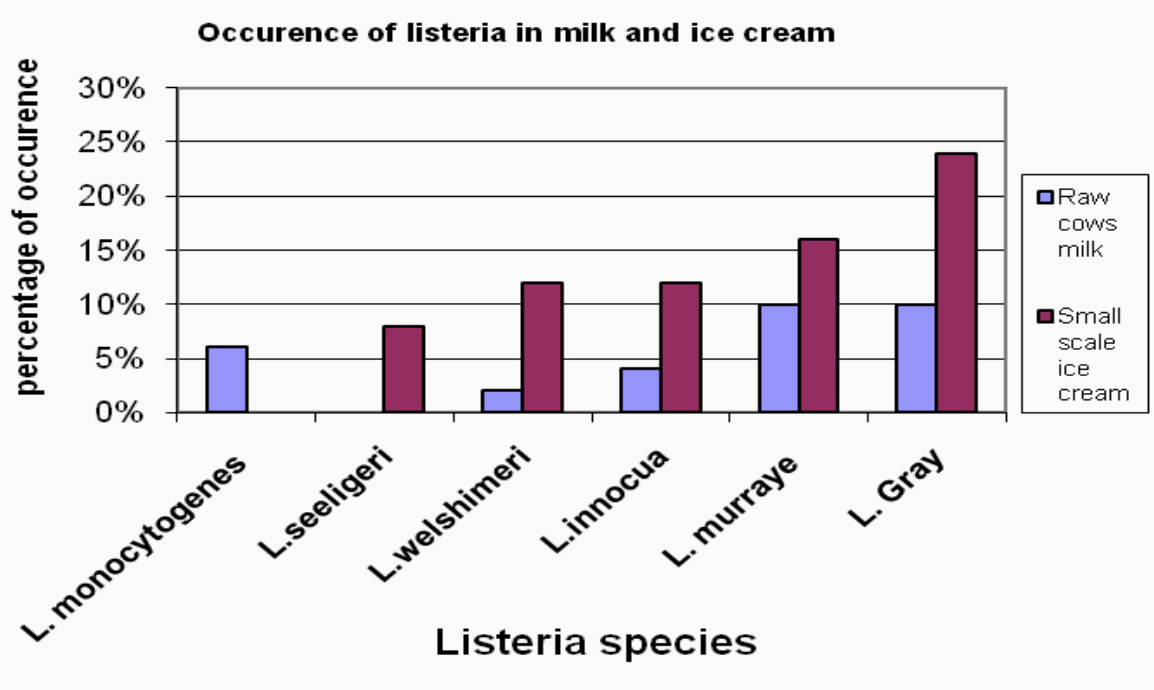




\section{DISCUSSION}

Listeria spp. could be detected in $15(30 \%)$ and $18(72 \%)$ of examined raw cow's milk and small scale ice cream samples respectively, while failed detection in large scale ice cream samples. L. welshimeri was identified in one sample (2\%) in raw cows milk, and 6 samples $(24 \%)$ in small scale ice cream, while L. innoccua present in 2 samples (4\%) of raw cow's milk, and in 6 samples $(24 \%)$ of small scale ice cream. L. murray was isolated in 4 samples ( $8 \%$ ) of raw cow's milk and 8 samples (32\%) of small scale ice cream. L. gray was detected in 5 samples $(10 \%)$ of raw milk and 12 samples $(48 \%)$ of small scale ice cream. Concerning L. monocytogenes, it has been recovered from 3 samples (6\%) of raw cow's milk and L. seeligeri was detected in $4(16 \%)$ of small scale ice cream (Tables $1 \& 2$ and Figures $1 \& 2)$

Listeria species are found almost in every medium in the environment; soil, canal waters, plants, animal feeds, and food. So, contamination of milk is possible by various means from these sources (Mclauchin, 1997). Listeria monocytogenes is the major wide spread human pathogens, the goal should be to exclude this organism from the food chain wherever possible and to maintain condition which will inhibit its multiplication in foods in which this bacteria can grow (WHO, 1988). The results in Table $1 \& 2$ and Figures $1 \& 2$ declared that the isolation rate of Listeria spp. in the examined raw cow's milk samples 15 positive samples represent $30 \%$. This incidence was slightly high in relation to the findings of Saito et al. (1991) $\{5.3 \%\}$; Harvey \& Gilmour (1992) \{25\%\}; Morales et al. (1995) \{7\%\}; Aman \&Ahmed (1997) \{3.33\%\}; Abdel Khalek \& El Gamal (1998) \{4\%\}; El-Prince (1999) $\{4 \%\}$; Salem (2000) $\{10 \%\}$.

In the present study, Listeria species isolated from raw cows milk was differentiated biochemicaly into 3 strains (6\%) including L. monocytogenes, L. innocua (4\%) and L. welshimeri (2\%).

Non pathogenic Listeria species were detected including L. murray (5 strains, $10 \%$ ) and L. gray (5 strains, (10\%). These results considered higher than that recorded by Davison et al. (1989) in raw milk in Canada. However, in USA Lovett et al. (1987); Rohrbach et al. (1992) and Jayarao and Hennig (2001) recorded 4.2, 4.4, and 4.6\%, respectively. In the same time, El- Prince and Sayed (2004) found $2 \%$ incidence of L. monocytogenes in Assiut governorate. In the public health significance L. monocytogenes could be transmitted to the consumers by ingestion of contaminated milk (Low \& Donachie, 1997). 
The organism causes typical gastrointestinal illness (Dalton et al., 1997). L. welshmeri pathogenesity to humans has been well documented (Cocolin et al., 2002). The investigation revealed the presence of the non pathogenic Listeria species.

It is Apparent from the results (Tables $1 \&$ 2and Figures $1 \& 2$ ) that ice cream produced in a large scale failed to show growth of Listeria species. These L species were recovered from 19 samples (76 \%) produced in a small scale.

High incidence of Listeria species in this study was higher in their incidencethan that of Pednekar et al., (1997) which recorded relatively lower incidence (28-42 \%) and Akman et al., (2004) found $41 \%$ incidence. Likewise lower incidence $(7.3 \%$ ) was recorded by Cotton\& White (1992), while Choi et al. (2001) could not isolate Listeria spp. from any of examined ice cream samples.

Further identification showed that L. monocytogenes could not be isolated from small scale ice cream samples. This result is confirmed by the work done by Akman et al. (2004) and El Prince and Sayed (2004).

Further more there is high incidence of L. seeligeri (16\%), L. welshime (24\%) and L. innocua (24\%). On the other hand L. monocytogenes was recovered from ice cream samples examined by Cotton \& White (1992) and Baek et al. (2000)

Listeria spp. have been isolated from pasteurized milk and ice cream in which contamination occured post production or recontaminated during further handling (Jeong and Frank, 1994 and El-Prince and Sayed, 2004.)

Listeriosis in humans are usually associated with haemolytic species of L. monocytogenes; L. ivanovi and L. seeligeri. However, L. welshimeri pathogenisity to humans has been well documented (Cocolin et al., 2002). The presence of any Listeria species in food may be an indicator of poor hygiene during handling and preparation of ice cream (Jeong \& Frank, 1994). Milk and dairy products under low temperature especially ice cream constitute a potential risk for Listeriosis (Maifreni et al., 1993). The presence of any species of Listeria is indicative for the potential presence of $L$. monocytogenes because the physiology and habitat of the different species of Listeria are very similar (Mclauchin et al., 1990 and Fedio \& Jackson, 1992).

The results in Table 3 showed that L. monocytogenes isolate from raw cow's milk samples belong to serotype 1, this result had been confirmed by Baek et al. (2000) who found that $90 \%$ of isolated Listeria belong to serotype 1 . 
Finally, the obtained results in this study prove the high incidence of Listeria species and speciaaly L. monocytogenes. This result could be considered as a public health risk factor on the consumers. Pasteurization still remains the $1^{\text {st }}$ line of defense against transmission of food born diseases through milk or dairy products.

\section{REFERENCES}

Abdel Khalek, A. and El Gamal, A. (1998): Occurrence of Listeria species in raw milk in Mansoura, Egypt. The $8^{\text {th }}$ Sci.Cong. Fac.Vet. Med. Assiut Univ., 57-64.

Akman, D.; Duran, N. and Digrak, M. (2004): Prevalence of L. species in ice cream sold in cities of Kahramanmaras and Adana. Turk. J. Med. Sci. 34: 257-262.

Aman, I.M. and Ahmed, H.F. (1997): Incidence and survival of some food-borne pathogens in milk and cheese. J. Amer. Vet. Med. Assoc., 200: 711-714.

Baek, S.Y.; S.Y. Lim, D.H. Lee, K.H. Min, and Kim, C.M.. (2000): Incidence and characterization of Listeria monocytogenes from domestic and imported foods in Korea. J. Food Prot. 63: 186189.

Choi, Y.C.; Cho, S.Y.; Park, P.K.; Chung, D.H. and Oh, D.H. (2001): Incidence and characterization of Listeria species from foods available in Korea. J., Food Prot., 64: 554-558.

Cocolin, L.; Rantsiou, K.; Iacumin, L.; Cantoni, C. and Conri, G. (2002): Direct identification in food samples of Listeria species and L. monocytogene by molecular methods Appl. Environ. Microbiol., 68(12): 6273-6282.

Cotton, L.N. and White, C.H. (1992): Listeria monocytogenes, Yersinia eneterocolitica, and Salmonella in dairy plant environments. J. Dairy Sci. 75: 51-57.

Cutris, G.D.W.; Mitchell, R.E.G.; King, A.F. and Griffin, E.J. (1989): A selective differential medium for the isolation of L. monocytogenes Lett. Appl. Microbiol., 8: 95-98.

Dalton, C.B.; Austin, C.C.; Sobel, J.; Hayes, P.S.; Bibb, W.B.; Graves, L.M.; Swaminathan, B.; Proctory, M.E. and Griffin, P.M. (1997): An outbreak of gastroenteritis and feverdue to $L$. monocytogenesin chocolate milk. N. Eng. J. Med., 336: 100105. 
Davison, R.J.; Sprung, D.W.; Park, C.E. and Rayman, M.K. (1989): Occurrence of L. monocytogenes, Campylobacter spp. and Yersinia enterocolitica in Manitoba raw milk. Can. Inst. Food Sci. Teechnol. J. 22: 70

Difco laboratories (1984): Dico manual $10^{\text {th }}$ Ed., Dtroit, MI, pp. 520524.

El-Prince, E. (1999): Isolation of L. monocytogenes and other Listeria species from milk and some dairy products. Assiut Vet. Med. J. 40: 168-176.

El-Prince, E. and Sayed, A.S.M. (2004): A survey on the presense of Listeria species in raw milk, Ice cream and Human stools with characterization of some isolate By Sds-Page. Assiut Vet. Med. J. Vol. 50 101: 94-109.

El-Sharef, N.; Ghenghesh, K.S.; Abognah, Y.S.; Gnan, S.O. and Rahouma, A. (2006): Bacteriological quality of ice cream in Tripoli-Libya. Food Contr. 17: 637-641.

El-Sherbini, M. and Abdallah, M.I.M. (2003): Evaluation of Listeria rapid test and FDA for detection of listerias in unpasteurized cream and market raw milk. $2^{\text {nd }}$ ICOFHHH, 21-23 October, Assiut- Egypt: 131-134.

Farber, J.M. and Peterkin, P.L. (1991): L. monocytogenes, a food-borne pathogen. Microbiol. Rev, 55:476-511.

Fedio, W.M. and Jackson, H. (1992): On the origin of Listeria monocytogenes in raw bulk-tank milk. Int. Dairy J. 2, 197-208.

Greenwood, M.H.; Roberts, D. and Burden, P. (1991): The occurrence of Listeria species in milk and dairy products: A national survey in England and Wales. Int. J. Food Microbiol. 12: 197206.

Griffiths, M.W. (1989): Listeria monocytogenes: its importance in the dairy industry, J. Sci. Food Agric. 47, 133-158

Harvey, J. and Gilmour, A. (1992): Occurrence of Listeria species in raw milk and dairy products produced in Northern Ireland. J. Appl. Bacteriol. 72, 119-125.

Hird, D.W. and Genigeogis, C. (1990): Listeriosis in food animals clinical signs and livestock as a potential source of direct (nonfoodborne) infection for humans. In Food borne Listeriosis (Eds A.J. Miller, J. L. Smithand G.A. Sumkuti) pp. 31-39. Amesterdam, Elsevier Science Publishers. 
Hitchins, A.D. (1992): Listeria monocytogenes In: FDA Bacteriological Analysis Manual. $7^{\text {th }}$ Ed. pp. 141-151, Association of Analytical Chemists, Arlington, VA.

Jayarao, B.M. and Hennig, D.R. (2001): Prevalence of food-borne pathogens in bulk tank milk. J. Dairy Sci., 84 (10): 2157-2162.

Jeong, K. D. and Frank, J. F. (1994): Growth of Listeria monocytogenes at $10^{\circ} \mathrm{C}$ in Biofilms with microorganisms isolated from meat and dairy processing environments. J. Food Prot., 57: 576-586.

Kiss, R.; Tirczka, T.; Szita, G.; Bernath, S. and Csiko, G. (2006): Listeria monocytogenes food monitoring data and incidence of human listeriosis in Hungary, 2004. Int. J. Food Microbiol. 112: 71-74.

Lampert, I.M. (1975): Modern dairy products. $3^{\text {rd }}$ Ed., Chemical Publ.Co. Inc., New York.

Longhi, C.; Maffeo, A.; Penta, M.; Petrone, G.; Seganti, L. and Conte, M.P. (2003): Dtection of $L$ monocytogenes in Italian-style soft cheeses. J. Appl. Microbiol., 94: 879-885.

Lou, Y and Yousef, A.E. (1999): Characterization of L. monocytogenes important to food processors, In: Listeria, Literiosis and food Safety. $2^{\text {nd }}$ Ed., pp.131-224 E.T Ryser and F.H. Marth (eds) Marcel Dekker Int., New York.

Lovett, J., Francis, D.W. and Hunt, J.M. (1987): Listeria monocytogenes in raw milk: detection, incidence and pathogenicity. J. Food Protect. 50, 188-192.

Low, J.C. and Donachie, W. (1997): A review of L. monocytogenes and listeriosis. Veterinary Journal, 153: 9-29.

Maifreni, M.; Civilini, M. and Domenis, C. (1993): Microbiological quality of artisan ice cream. Zentrabi Hyg. Umweltmed 194: 553-70.

Meldrun, R.J.; Riberro, C.D.; Smith, R.M.M.; Walker, A.M.; Simmons, M.; Worthington, D. and Edwards, C. (2005): microbiological quality of ready-to-eat foods: Results from a long term surveillance program (1995through 2003). J. Food Prot. 68: 1654-1658.

Mclauchin, J.; Greenwood, M.H. and Pini, P.N. (1990): the occurrence of Listeria monocytogenes in cheese from a manufacturer associated with a case of Listeriosis. Int. J. Food Microbiol. 10: 255.

McLauchlin, J. (1997): The identifcation of Listeria species. Int J. Food Microbiol. 38: 77-81. 
Molla, B.; Roman, Y. and Alemayehu, D. (2004): Listeria monocytogenes and other Listeria species in retailmeat and milk products in Addis Abbaba, Ethiopia, Ethiop. J. Health Dev. 18: 208-212.

Morales, A.L.; DeLa, A.O.; Sandoval, V. and Barbosa, R. (1995): Prevvalenceof L monocytogenes in raw milk in Guadalajara, Mexico, J. Food Prot., 58 (10): 1139-1141.

Pak, S.I.; Spahr, U.; Jemmi, T. and Salman, M.D. (2002): Risk factors for $L$ monocytogenes contamination of Dairy products in Switzerland, 1990-1999. Prev. Vet. Med. 53: 55-65.

Pedneckar, M.D.; Kamat, A.S. and Adhikari, H.R. (1997): Incidence of L. species in milk and milk products. Ind. J. Dairy Sci., 50(2): 142-151.

Rohrbach, R.W.; Draughon, F.A.; Davidson, P.M. and Oliver, S.P. (1992): prevailance of L. monocytogenes Campylobacter jejuni, yersinia enterocolitica and salmonella in bulk tank milk: risk factors and risk of human exposure. J. Food Prot, 55: 9397.

Saito, A.; Tokumaru, Y.; Masak, M.; Taya, T. and Aoki, A. (1991): Evaluation of enrichment and plating media for the isolation of L. monocytogenes from raw milk and contamination of raw milk by Listeria. J. Jap. Vet. Med. Assoc., 44: 378-383.

Salem, E.M. (2000): Studies on Listeria microorganisms in milk and some milk products $\mathrm{Ph}$ D. Thsis, Fac. Vet. Med., Suez Canal Univ.

Schlech, W.F.; III, P.; Lavigne, M.; Hightower, A.W.; Johnson, S.E.; King, S.H.; Nicolls, E.S. and Broome, C.V. (1983): Epidemic listeriosis-Evidence for transmission by food. N. Engl. J. Med. 308: 203-206.

Warburton, D.; Boville, Ann Pagotto, F. Daley Elaine and Chow Clindy (2003): The detection of Listeria spp. in foods and environmental samples using palcam broth. Health products and food branch (HPFB) Ottawa, Ontario.

World Health Organization (1988): Foodborn listeriosis. Report of a WHO Informal Working Group Genova 15-9. 